\title{
TRENDS IN EXTREME DAILY PRECIPITATION INDICES IN BOSNIA AND HERZEGOVINA
}

\author{
Tatjana Popov ${ }^{*}$, Slobodan Gnjato*, Goran Trbić, Marko Ivanišević ${ }^{*}$ \\ "University of Banja Luka - Faculty of Natural Sciences and Mathematics, Banja Luka, \\ Bosnia and Herzegovina
}

\begin{abstract}
The study investigates trends in extreme daily precipitation indices in Bosnia and Herzegovina. A set of daily precipitation time series from four meteorological stations was used for the computation of 13 indices (mostly recommended by the ETCCDI). Trends were calculated for the 1961-2015 periods using RClimDex (1.0) software package. Given the results, a general increase in the extreme precipitation indices is present over the territory of Bosnia and Herzegovina. Upward trends in heavy precipitation indices such as RX1day, RX5day, SDII, R10mm, R20mm, R95p, $\mathrm{R} 95 \mathrm{p} \%$, R99p and R99p\% indicate changes toward more intense precipitation in Bosnia and Herzegovina. However, most of the estimated trends are not statistically significant. Registered patterns of change were not spatially and temporally coherent and one of the characteristics was that trend signs were mixed. The analyzed precipitation indices trends are directly linked to changes in the dominant large-scale circulation patterns over Northern Hemisphere. Statistically significant negative correlation with $\mathrm{NAO}$, EAWR and $\mathrm{AO}$ is found for majority of extreme precipitation indices, particularly strong during winter. Due to their large impact on natural and socio-economic systems, further research on extreme precipitation events is certainly necessary.
\end{abstract}

Key words: precipitation extremes, indices, trend, climate change, Bosnia and Herzegovina.

${ }^{1}$ Corresponding author: T. Popov, University of Banja Luka - Faculty of Natural Sciences and Mathematics, Dr. Mladena Stojanovića 2, 78,000 Banja Luka, Bosnia and Herzegovina; e-mail: tatjana.popov@pmf.unibl.org 


\section{Introduction}

Study and understanding of changes in extreme precipitation events is of great importance because of their large impact on society and ecosystems compared to changes in mean precipitation (Hartmann et al., 2013). Records around the world have shown mixed and non-significant long-term trends in mean precipitation changes (Hartmann et al., 2013). However, averaged over the Northern Hemisphere mid-latitudes, precipitation has increased since 1951 (Intergovernmental Panel on Climate Change [IPCC], 2014). IPCC has reported that substantial increases were found in annual heavy precipitation events (disproportionately high compared to changes in mean precipitation) over many mid-latitude regions between 1951 and 2003, even in the regions where a reduction in annual total precipitation had been observed (Hartmann et al., 2013).

Given that in Bosnia and Herzegovina during the last decade increased frequency of years with extreme precipitation (years with high precipitation and catastrophic floods and years with a very low precipitation and prolonged droughts) has been observed, the preparation of a research on extreme precipitation trends became necessary. Particularly, due to the large impact of extreme precipitation events on the natural and socio-economic systems.

The paper is divided into 4 sections. Section 1 gives an overview of previous research. Section 2 describes data and methods used in the study. Section 3 contains results of extreme precipitation indices trend calculations and in addition, the correlation analysis of the observed extreme precipitation trends and the large-scale circulation patterns. Section 4 sets the conclusion. At the end, there is a literature overview.

\section{Previous research}

Global scale studies suggest that, in general, changes in precipitation extremes are consistent with a wetter climate (Donat et al., 2013; Hartmann et al., 2013). There are more regions in the world where the number of heavy precipitation events (i. e. its amounts, intensity, and frequency) has increased than those where it decreased (Donat et al., 2013; IPCC, 2014). Although global scale studies found a general increase in the extreme precipitation indices, they showed less spatially coherent patterns of change and only small scale trends that have lower level of statistical significance (Donat et al., 2013). Contrary, the consistent warming trends were globally reported for the extreme temperature indices (Donat et al., 2013). Most of the extreme 
precipitation indices (e. g. RX5day, R10mm, R95p and SDII) show significant changes toward more intense precipitation over numerous regions in the world, but results are not homogeneous in space and time, and form season to season (Donat et al., 2013). Globally, there has been a steady decline in consecutive dry days (CDD) since the 1960s. It also suggests wetter conditions. Shorter duration of dry spells is present over much of Eurasia (Donat et al., 2013). Results of these global analyses that found trends mixed in sign and spatially incoherent were confirmed by numerous regional and local studies all over the Europe (Bartolomeu et al., 2016; de Lima et al., 2015), Asia (Balling Jr. et al., 2016; Fan and Chen, 2016; Sheikh et al., 2015), Africa (Filahi et al., 2016), America (de Melo et al., 2015; Santos and de Oliveira, 2017) and Australia (Alexander and Arblaster, 2017).

In Europe, there have been likely increases in either the frequency or intensity of heavy precipitation (Hartmann et al., 2013). Global analysis of observed trends in extreme precipitation indices were also reported by previous studies in the Southeast Europe region were Bosnia and Herzegovina is located. Heterogeneous changes of annual precipitation, i.e. trends mixed in sign, have been detected in Serbia (Luković et al., 2014), Croatia (GajićČapka et al., 2015), Slovenia (de Luis et al., 2014) and Montenegro (Burić et al., 2015). Trends were predominantly weak and insignificant. Seasonal precipitation also showed trends of both signs - for example in Serbia and Montenegro winter and spring precipitation decreased, whereas autumn increased (Burić et al., 2015; Luković et al., 2014). In Croatia, negative trends were found for summer season, whereas upward in autumn (Gajić-Čapka et al., 2015). Trends in extreme precipitation indices in this part of Europe were mainly weak and mixed in sign - however, the regional results generally suggest that precipitation intensity increased (Burić et al., 2015; Gajić-Čapka et al., 2015; Unkašević and Tošić, 2011).

This study is a continuation of the previuos research (Ducić et al., 2014; Mihailović et al., 2015) on precipitation variability and recent climate change in Bosnia and Herzegovina. This territory has been so far poorly documented in terms of trends in precipitation extremes and this kind of studies has not been previously conducted for this area. The main aim of this study was twofold: 1. To compute and analyze trends in extreme precipitation indices over Bosnia and Herzegovina during the 1961-2015 periods. 2. To investigate the relation between observed trends and the large-scale circulation patterns.

Study of this kind can be a useful source of data in a variety of applied research, primarily in the fields of hazard risks management (Miladinović 
and Gavrilović, 2012), agricultural planning (Milinčić et al., 2013) and sustainable tourism (Živanović, 2014; Lojović and Gnjato, 2016; Rvović, 2014).

\section{Data and methods}

The analysis of trends in extreme precipitation indices during 19612015 periods was carried out using climatological data set of a daily precipitation from four meteorological stations in Bosnia and Herzegovina (that represents all of the available daily data): Banjaluka (BL), Doboj (DB), Sarajevo (SA) and Mostar (MO) (Figure 1). The selected meteorological stations covered all three physical macroregions of Bosnia and Herzegovina: Peripannonian, Dinaric and Submediterranean. Data were provided by the Federal Hydrometeorological Institute Sarajevo and the Republic Hydrometeorological Service of the Republic of Srpska. During the observed period stations did not change their location and there were no interruptions in measurements (only at DB station during the war period 1992-1996).

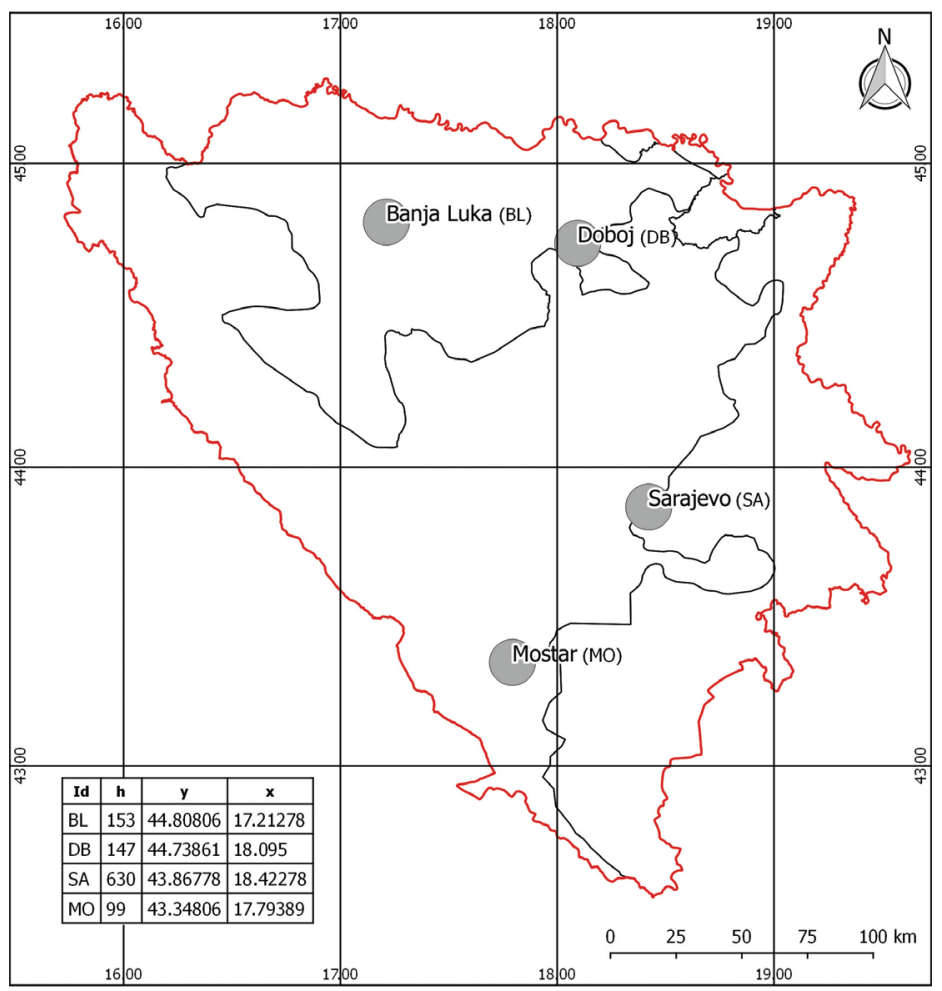

Figure 1 - The geographical location of study area 
The recent precipitation variability in Bosnia and Herzegovina has been determined by trends in annual and seasonal mean precipitation and by trends in extreme precipitation indices. A set of 10 climate indices recommended by the $\mathrm{CCl} / \mathrm{CLIVAR}$ Expert Team for Climate Change Detection Monitoring and Indices (ETCCDI, 2009) were selected (Table 1). In addition, a few more indices derived from them have been also analyzed - R1mm, R95p \% and R99p \%.

Table 1 - Definitions of the indices used in the study

\begin{tabular}{|c|c|c|c|}
\hline Index & Descriptive name & Definition & Units \\
\hline PRCPTOT & $\begin{array}{l}\text { Annual total wet-day } \\
\text { precipitation }\end{array}$ & Annual total precipitation in wet days & $\mathrm{mm}$ \\
\hline RX1day & $\begin{array}{l}\text { Highest 1-day } \\
\text { precipitation amount }\end{array}$ & Monthly maximum 1-day precipitation & $\mathrm{mm}$ \\
\hline RX5day & $\begin{array}{l}\text { Highest 5-day } \\
\text { precipitation amount }\end{array}$ & $\begin{array}{l}\text { Monthly maximum consecutive 5-day } \\
\text { precipitation }\end{array}$ & $\mathrm{mm}$ \\
\hline SDII & $\begin{array}{l}\text { Simple pricipitation } \\
\text { intensity index }\end{array}$ & $\begin{array}{l}\text { Annual total precipitation divided by } \\
\text { the number of wet days in the year }\end{array}$ & $\begin{array}{r}\mathrm{mm} / \\
\text { day }\end{array}$ \\
\hline R1mm & Number of wet days & $\begin{array}{l}\text { Annual count of days when } \\
\text { precipitation }>=1 \mathrm{~mm}\end{array}$ & days \\
\hline $\mathrm{R} 10 \mathrm{~mm}$ & $\begin{array}{l}\text { Number of heavy } \\
\text { precipitation days }\end{array}$ & $\begin{array}{l}\text { Annual count of days when } \\
\text { precipitation }>=10 \mathrm{~mm}\end{array}$ & days \\
\hline $\mathrm{R} 20 \mathrm{~mm}$ & $\begin{array}{l}\text { Number of very heavy } \\
\text { precipitation days }\end{array}$ & $\begin{array}{l}\text { Annual count of days when } \\
\text { precipitation }>=20 \mathrm{~mm}\end{array}$ & days \\
\hline R95p & Very wet days & $\begin{array}{l}\text { Annual total precipitation when daily } \\
\text { precipitation amount }>95 \text { th percentile }\end{array}$ & $\mathrm{mm}$ \\
\hline R99p & Extremely wet days & $\begin{array}{l}\text { Annual total precipitation when daily } \\
\text { precipitation amount }>99 \text { th percentile }\end{array}$ & $\mathrm{mm}$ \\
\hline R95p \% & $\begin{array}{l}\text { Precipitation fraction } \\
\text { due to very wet days }\end{array}$ & $\begin{array}{l}\text { Percentage of annual total wet-day } \\
\text { precipitation due to events with } \\
\text { precipitation }>95 \text { th percentile }\end{array}$ & $\%$ \\
\hline $\mathrm{R} 99 \mathrm{p} \%$ & $\begin{array}{l}\text { Precipitation fraction } \\
\text { due to extremely wet } \\
\text { days }\end{array}$ & $\begin{array}{l}\text { Percentage of annual total wet-day } \\
\text { precipitation due to events with } \\
\text { precipitation }>99 \text { th percentile }\end{array}$ & $\%$ \\
\hline CDD & Consecutive dry days & $\begin{array}{l}\text { Maximum number of consecutive days } \\
\text { with daily precipitation amount }<1 \mathrm{~mm}\end{array}$ & days \\
\hline CWD & Consecutive wet days & $\begin{array}{l}\text { Maximum number of consecutive days } \\
\text { with daily precipitation amount }>=1 \mathrm{~mm}\end{array}$ & days \\
\hline
\end{tabular}


The selected indices can be divided into 4 different categories:

1. Absolute extreme indices: RX1day, Rx5day and SDII.

2. Absolute-based (fixed) threshold indices defined as the number of days on which a precipitation value falls above a fixed threshold: R1mm, R10mm and R20mm.

3. Percentile-based (non-fixed) threshold indices: R95p, R95p\%, R99p and R99p\%. The 1961-1990 periods was set as the base period for determining the frequency distribution for the this indices.

4. Duration-based indices (spell indices) defined as periods of excessive wet and dry periods: CDD and CWD.

The indices were calculated using RClimDex (1.0) software package developed at Climate Research Division Environment Canada (Zhang and Yang, 2004). Data quality control in RClimDex showed that no outliers in daily precipitation time series were found at all stations. Trends in extreme precipitation indices were computed in RClimDex by linear least square method and locally weighted linear regression (dashed line on plots). Statistics of the linear trend fitting are also displayed on the plots. Trends have been analyzed by stations individually and then the trend for the whole territory of Bosnia and Herzegovina has been calculated. The average data series of extreme precipitation indices for Bosnia and Herzegovina were subjected to the nonparametric Mann-Kendall test. Trend magnitude was determined by the Sen's nonparametric estimator of slope. Calculations were made in XLSTAT Version 2014.5.03. The statistical significance of the observed trends was defined at the $99 \%$ ( $p$ value $\leq 0.01), 95 \%(0.01<\mathrm{p}$ value $\leq 0.05), 90 \%(0.05<\mathrm{p}$ value $\leq 0.10)$ and $75 \%(0.10<$ p value $\leq 0.25)$ level.

In order to explain the relationship between the observed precipitation trends in Bosnia and Herzegovina and the large-scale atmospheric circulations, the dominant Northern Hemisphere teleconnection patterns have been investigated. The three primary modes of atmospheric circulation variability over the North Atlantic - the North Atlantic Oscillation (NAO), the EastAtlantic (EA) pattern and the East Atlantic/West Russia (EAWR) pattern - and the Arctic Oscillation (AO) have been analyzed. Data on these largescale atmospheric circulation indices were collected from NOAA National Weather Service Climate Prediction Center (NOAA CPC, 2017). For quantification of the relation between the analyzed extreme precipitation indices and the large-scale circulation patterns, the Pearson correlation coefficient was used. The coefficients were calculated on annual and seasonal levels for 
state averaged indices. The statistical significance of the determined correlations was defined at the $99.9 \%$ ( $p$ value $\leq 0.001), 99 \%(0.001<p$ value $\leq 0.01), 95$ $\%(0.01<\mathrm{p}$ value $\leq 0.05)$ and $90 \%(0.05<\mathrm{p}$ value $\leq 0.10)$ level.

\section{Results and discussion}

Statistical parameters of annual precipitation time series for the meteorological stations used in the study are given in Table 2. Table 3 shows regional mean annual and seasonal precipitation for the two periods - for whole study period $(1961-2015)$ and the standard climatological period (1961-1990). Mean annual precipitation during the 1961-2015 periods in Bosnia and Herzegovina is $1102 \mathrm{~mm}$. In general, the sum of the annual precipitation increases with altitude toward central and southern part of the territory. In the northern lowland areas, maximum and minimum precipitation are typical of summer and winter season, respectively. In contrary, in Herzegovina region, in the southern part of the territory, maximum precipitation occurrs in colder part of the year - in winter and autumn, whereas substantially less precipitation is present during summer season.

Table 2 - Statistical parameters of annual precipitation time series of the meteorological stations used in the study

\begin{tabular}{|c|c|c|c|c|c|c|c|}
\hline 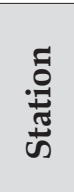 & 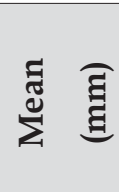 & 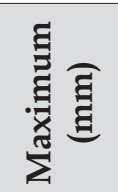 & 㓥 & 窝 & $\vec{u} e^{a}$ & 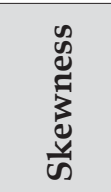 & 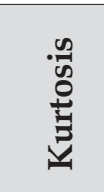 \\
\hline BL & 1040.1 & 1686.2 & 588.2 & 186.6 & 17.9 & 0.476 & 1.864 \\
\hline DB & 928.8 & 1494.5 & 504.1 & 193.8 & 20.9 & 0.709 & 0.922 \\
\hline SA & 942.2 & 1248.9 & 626.0 & 146.6 & 15.6 & -0.187 & -0.645 \\
\hline $\mathrm{MO}$ & 1495.7 & 2490.7 & 840.0 & 336.5 & 22.5 & 0.253 & 0.418 \\
\hline
\end{tabular}

Note: STDEV - standard deviation, CV - coefficient of variation 
Table 3 - Annual and seasonal mean precipitation in Bosnia and Herzegovina in 1961 2015 (a) and $1961-1990(b)(\mathrm{mm})$

\begin{tabular}{|l|c|c|c|c|c|c|c|c|c|c|}
\hline \multirow{2}{*}{ Season } & \multicolumn{2}{|c|}{ BL } & \multicolumn{2}{c|}{ DB } & \multicolumn{2}{c|}{ SA } & \multicolumn{2}{c|}{ MO } & \multicolumn{2}{c|}{ BIH } \\
\cline { 2 - 11 } & $\mathbf{a}$ & $\mathbf{b}$ & $\mathbf{a}$ & $\mathbf{b}$ & $\mathbf{a}$ & $\mathbf{b}$ & $\mathbf{a}$ & $\mathbf{b}$ & $\mathbf{a}$ & $\mathbf{b}$ \\
\hline Winter & 227 & 220 & 198 & 188 & 227 & 224 & 486 & 495 & 284 & 282 \\
\hline Spring & 266 & 264 & 231 & 221 & 227 & 226 & 356 & 379 & 270 & 272 \\
\hline Summer & 283 & 299 & 274 & 263 & 232 & 242 & 191 & 196 & 245 & 250 \\
\hline Autumn & 267 & 246 & 228 & 200 & 259 & 241 & 468 & 450 & 305 & 284 \\
\hline Year & 1040 & 1029 & 929 & 870 & 942 & 932 & 1496 & 1523 & 1102 & 1088 \\
\hline
\end{tabular}

An overview of the average annual values of the extreme precipitation indices in the observed period $(1961-2015)$ and in the standard climatological period (1961-1990) is given in Table 4.

Table 4 - Average values of extreme precipitation indices in Bosnia and Herzegovina in $1961-2015$ (a) $1961-1990$ (b)

\begin{tabular}{|c|c|c|c|c|c|c|c|c|c|c|}
\hline \multirow{2}{*}{ Index } & \multicolumn{2}{|c|}{ BL } & \multicolumn{2}{c|}{ DB } & \multicolumn{2}{c|}{ SA } & \multicolumn{2}{c|}{ MO } & \multicolumn{2}{c|}{ BIH } \\
\cline { 2 - 13 } & $\mathbf{a}$ & $\mathbf{b}$ & $\mathbf{a}$ & $\mathbf{b}$ & $\mathbf{a}$ & $\mathbf{b}$ & $\mathbf{a}$ & $\mathbf{b}$ & $\mathbf{a}$ & $\mathbf{b}$ \\
\hline PRCPTOT & 1023 & 1012 & 903 & 854 & 924 & 914 & 1485 & 1512 & 1088 & 1073 \\
\hline RX1day & 55 & 54 & 49 & 45 & 50 & 49 & 81 & 77 & 59 & 56 \\
\hline RX5day & 97 & 95 & 84 & 75 & 85 & 81 & 154 & 153 & 106 & 101 \\
\hline SDII & 9 & 9 & 8 & 8 & 8 & 8 & 14 & 14 & 10 & 10 \\
\hline R1mm & 111 & 113 & 91 & 110 & 114 & 114 & 103 & 106 & 105 & 111 \\
\hline R10mm & 36 & 35 & 30 & 29 & 31 & 31 & 48 & 49 & 37 & 36 \\
\hline R20mm & 13 & 13 & 10 & 9 & 10 & 9 & 25 & 26 & 15 & 14 \\
\hline R95p & 232 & 212 & 221 & 176 & 201 & 202 & 332 & 316 & 247 & 227 \\
\hline R99p & 75 & 66 & 82 & 50 & 61 & 56 & 110 & 84 & 82 & 64 \\
\hline R95p\% & 22 & 20 & 23 & 20 & 21 & 22 & 22 & 21 & 22 & 21 \\
\hline R99p\% & 7 & 6 & 8 & 6 & 6 & 6 & 7 & 6 & 7 & 6 \\
\hline CDD & 23 & 21 & 24 & 24 & 22 & 23 & 30 & 30 & 25 & 25 \\
\hline CWD & 7 & 6 & 6 & 6 & 7 & 7 & 9 & 9 & 7 & 7 \\
\hline
\end{tabular}

Decadal trends in annual and seasonal precipitation in Bosnia and Herzegovina in the 1961-2015 periods are shown in Table 5. The estimated trends in mean annual precipitation are not spatially coherent. Trends of both signs were reported. The only positive trend was registered in Doboj (19.69 $\mathrm{mm}$ per decade), whereas the most prominent negative trend was present in the south, in Mostar (-42.50 mm per decade). Similar patterns of change were 
found for PRCPTOT (annual total of precipitation in days when precipitation amount is $>=1 \mathrm{~mm}$ ). Analysis of seasonal precipitation trends showed that negative trends were reported in summer over the entire territory (most pronounced in Banjaluka - $-15.63 \mathrm{~mm}$ per decade). In autumn, the positive trends were found all over the study area, whereas trends for winter and spring were regionally mixed in signs. All of these seasonal trends of both signs are not statistically significant. It should be noted that the strongest negative trends throughout the year were reported for southern (submediterranean) areas (except in autumn when a slight increase has been observed).

Table 5 - Decadal trends in annual and seasonal precipitation in Bosnia and Herzegovina in $1961-2015$

\begin{tabular}{|c|c|c|c|c|c|}
\hline Station & Winter & Spring & Summer & Autumn & Year \\
\hline BL & 1.90 & 0.00 & $-15.63^{\mathrm{d}}$ & $9.44^{\mathrm{d}}$ & -9.79 \\
\hline DB & 0.83 & 7.50 & -4.48 & $10.00^{\mathrm{d}}$ & 19.69 \\
\hline SA & -3.05 & 3.32 & -4.94 & 3.53 & -0.68 \\
\hline MO & -12.78 & $-12.04^{\mathrm{d}}$ & $-8.50^{\mathrm{d}}$ & 2.00 & $-42.50^{\mathrm{d}}$ \\
\hline
\end{tabular}

Note: Statistical significance at the $99 \%\left({ }^{\mathrm{a}}\right), 95 \%\left({ }^{\mathrm{b}}\right), 90 \%\left({ }^{(}\right)$and $75 \%\left({ }^{\mathrm{d}}\right)$ level

Results of the analysis of trends in annual absolute extreme indices and absolute-based threshold indices are given in Table 6 and Figures 2-4. The obtained results indicate a general increase in the extreme precipitation indices. When compared with temperature changes (Trbić et al., 2017), a less spatially coherent pattern of change was registered. Most of the estimated trends are not statistical significant.

Table 6 - Decadal trends in annual absolute extreme indices and absolute-based threshold indices in Bosnia and Herzegovina in $1961-2015$

\begin{tabular}{|c|c|c|c|c|c|c|c|}
\hline Station & $\begin{array}{c}\text { PRCP } \\
\text { TOT }\end{array}$ & $\begin{array}{c}\text { RX1 } \\
\text { day }\end{array}$ & $\begin{array}{c}\text { RX5 } \\
\text { day }\end{array}$ & SDII & R1mm & R10mm & R20mm \\
\hline BL & -2.06 & -0.38 & -0.41 & 0.05 & -1.22 & 0.05 & 0.18 \\
\hline DB & $21.18^{\mathrm{d}}$ & $2.25^{\mathrm{d}}$ & $6.00^{\mathrm{b}}$ & $0.22^{\mathrm{b}}$ & -0.84 & 0.50 & $0.46^{\mathrm{d}}$ \\
\hline SA & 0.83 & 0.83 & 2.12 & 0.07 & -1.01 & 0.11 & 0.15 \\
\hline MO & -22.47 & $2.52^{\mathrm{d}}$ & 0.98 & 0.10 & $-2.49^{\mathrm{c}}$ & -0.78 & -0.59 \\
\hline
\end{tabular}

Note: Statistical significance at the $99 \%\left({ }^{\mathrm{a}}\right), 95 \%\left({ }^{\mathrm{b}}\right), 90 \%\left({ }^{\mathrm{c}}\right)$ and $75 \%\left({ }^{\mathrm{d}}\right)$ level 

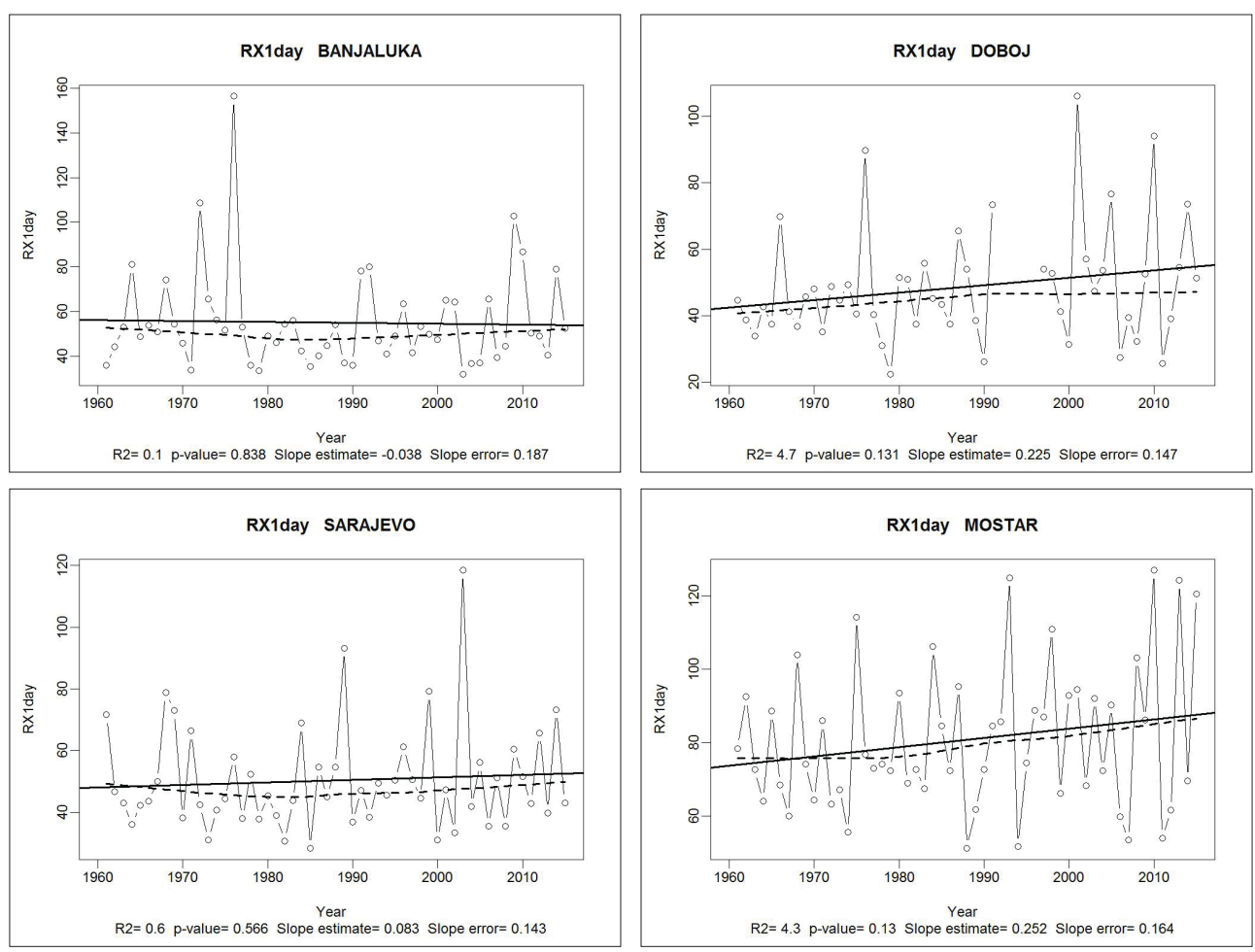

Figure 2 - Linear trends in RX1day in Bosnia and Herzegovina in 1961 - 2015

Rare precipitation events (such as the highest annual daily precipitation total) have increased since the 1960. Maximum 1-day precipitation amount (RX1day) has been increasing in all areas, except in Banjaluka where very weak negative trend was registered. Simmilar pattern of change was found for RX5day. Maximum consecutive 5-day precipitation showed statistically significant $(\mathrm{p}<0.05)$ upward trend in Doboj area $(6.00 \mathrm{~mm}$ per decade). Simple pricipitation intensity index (SDII) showed increasing trend, that was significant $(p<0.05)$ only at Doboj station $(0.22 \mathrm{~mm} /$ day per decade). The negative trends in annual number of wet days (in the range of $-0.84--2.49$ days per decade) and upward trends in numbers of heavy precipitation days and very heavy precipitation days (in the range of $0.05-0.50$ and $0.15-0.46$ days per decade, respectively) indicate changes toward more intense precipitation. Only in Mostar area, heavy and very heavy precipitation have decreased. Much larger decline was recorded for R1mm suggesting drier 
conditions in this submediterranean part of the country.
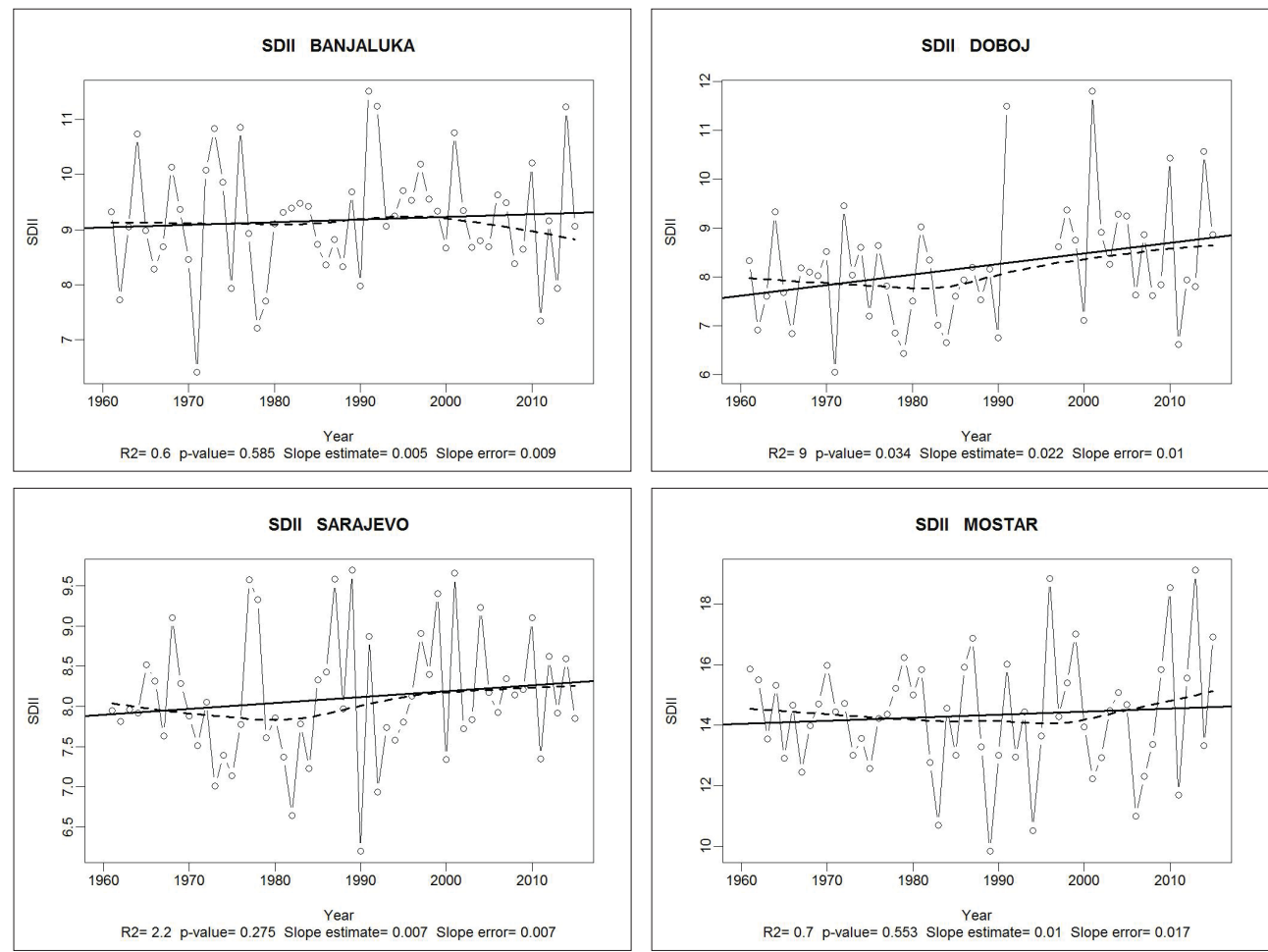

Figure 3 - Linear trends in SDII in Bosnia and Herzegovina in 1961 - 2015

The only two of the extreme precipitation indices that have been calculated seasonally (RX1day and RX5day) show that spatially and temporally (seasonally) trends mixed in sign were present (Table 7). Maximum 1-day precipitation amount decreased in summer over the entire territory, whereas increased in autumn. In winter and spring, RX1day did not display a coherent pattern of change. RX5day showed upward trend during spring, autumn and winter (only in the northern part). All trends are mostly not significant. 
Table 7 - Decadal trends in seasonal RX1day and RX5day in Bosnia and Herzegovina in 1961-2015

\begin{tabular}{|c|c|c|c|c|c|c|c|c|}
\hline \multirow{2}{*}{ Station } & \multicolumn{5}{|c|}{ RX1day } & \multicolumn{5}{c|}{ RX5day } \\
\cline { 2 - 10 } & Winter & Spring & Summer & Autumn & Winter & Spring & Summer & Autumn \\
\hline BL & $1.06^{\mathrm{d}}$ & -0.08 & -0.69 & 0.04 & 0.31 & 1.33 & -2.07 & 1.63 \\
\hline DB & 0.55 & $1.36^{\mathrm{c}}$ & -0.76 & 1.19 & 0.6 & $4.83^{\mathrm{b}}$ & -0.79 & $3.20^{\mathrm{d}}$ \\
\hline SA & -0.18 & -0.92 & -0.06 & $2.00^{\mathrm{c}}$ & -2.2 & 1.00 & -0.89 & $2.40^{\mathrm{d}}$ \\
\hline MO & $-1.50^{\mathrm{d}}$ & 0.64 & -1.23 & 1.70 & -1.17 & 1.18 & 1.03 & 0.87 \\
\hline
\end{tabular}

Note: Statistical significance at the $99 \%\left({ }^{\mathrm{a}}\right), 95 \%\left({ }^{\mathrm{b}}\right), 90 \%\left({ }^{(}\right)$and $75 \%\left({ }^{\mathrm{d}}\right)$ level
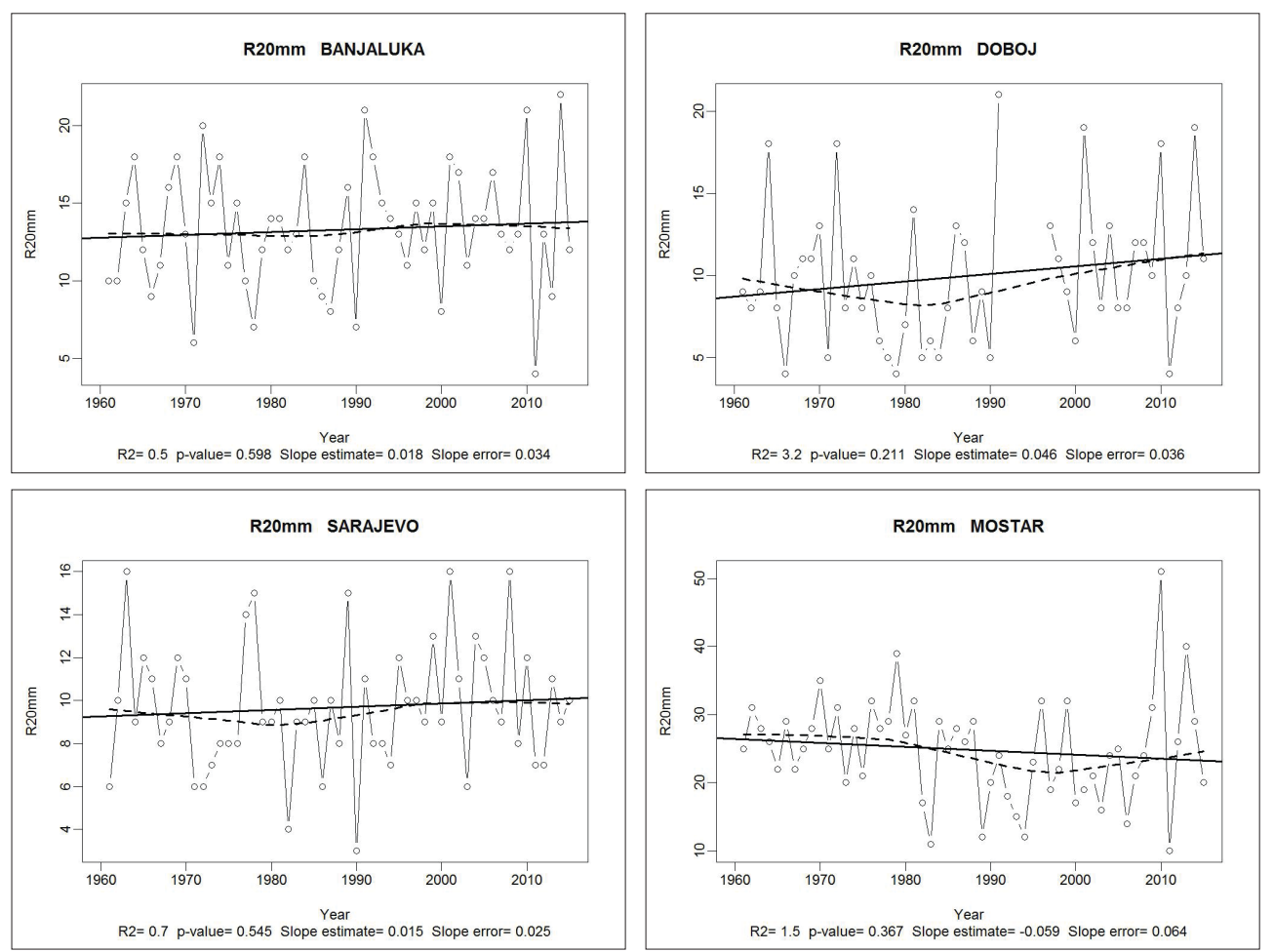

Figure 4 - Linear trends in R20mm in Bosnia and Herzegovina in 1961 - 2015

Analysis of decadal trends in annual percentile-based indices (Table 8 and Figure 5) showed that the (percentage) contribution from very wet days and extremely wet days to the annual precipitation total have increased over almost the entire territory of Bosnia and Herzegovina, although trends were mostly insignificant. 
Trends in Extreme Daily Precipitation Indices in Bosnia and Herzegovina

Table 8 - Decadal trends in annual percentile-based and duration-based indices in Bosnia and Herzegovina in $1961-2015$

\begin{tabular}{|c|c|c|c|c|c|c|}
\hline Station & $\mathbf{R 9 5 p}$ & $\mathbf{R 9 5} \mathbf{p}^{\mathbf{0}}$ & $\mathbf{R 9 9} \mathbf{p}$ & $\mathbf{R 9 9} \mathbf{0} \%$ & $\mathbf{C D D}$ & $\mathbf{C W D}$ \\
\hline BL & 6.49 & 0.45 & 1.15 & 0.00 & $1.28^{\mathrm{b}}$ & $0.31^{\mathrm{c}}$ \\
\hline DB & $22.76^{\mathrm{b}}$ & $1.93^{\mathrm{c}}$ & $19.46^{\mathrm{b}}$ & $0.93^{\mathrm{c}}$ & 0.06 & $0.25^{\mathrm{c}}$ \\
\hline SA & -1.78 & -0.20 & 5.52 & 0.00 & -0.14 & -0.01 \\
\hline MO & 3.74 & 0.12 & $16.20^{\mathrm{c}}$ & $0.38^{\mathrm{d}}$ & -0.24 & 0.07 \\
\hline
\end{tabular}

Note: Statistical significance at the $99 \%\left({ }^{\mathrm{a}}\right), 95 \%\left({ }^{\mathrm{b}}\right), 90 \%\left({ }^{\mathrm{c}}\right)$ and $75 \%\left({ }^{\mathrm{d}}\right)$ level
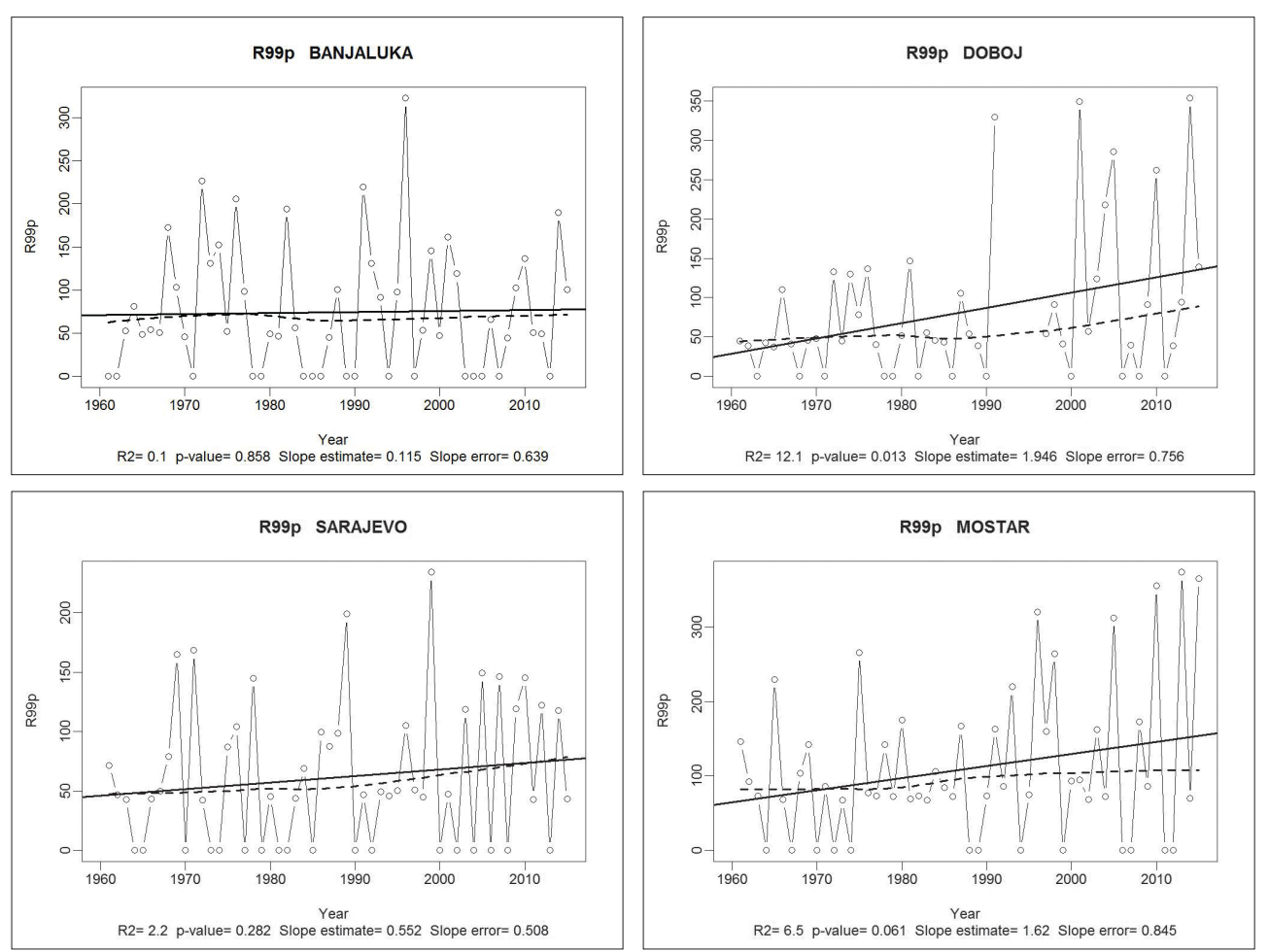

Figure 5 - Linear trends in R99p in Bosnia and Herzegovina in 1961 - 2015

The only statistically significant $(\mathrm{p}<0.05)$ positive trend in the annual R95p and R99p was registered in Doboj - $22.76 \mathrm{~mm}$ per decade and 19.46 $\mathrm{mm}$ per decade, respectively. The estimated trend in Mostar $(16.20 \mathrm{~mm}$ per decade) is significant only at the $10 \%$ level. Duration-based indices displayed spatially incoherent trends, which were mostly insignificant (Table 8). Maxi- 
mum number of consecutive dry days (CDD) showed trends mixed in sign. In the northern part of the territory CDD increased (in Banjaluka signicantly 1.28 days per decade), whereas steady decline in CDD in central, and particularly in south, has been present. Consecutive wet days (CWD) mostly showed upward trend during the observed period, more significant in the northern part of the territory $(0.25-0.31, \mathrm{p}<0.1 \%)$.

Although the observed trends are spatially not homogeneous and mainly statistically insignificant, the results indicate a general increase in the extreme precipitation. Similar patterns of change with trends of different sign (largely insignificant), seasonally and regionally, have been determined in other studies in the Southeast Europe region. Heavy precipitation indices (e. g. R20mm, $\mathrm{R} 95 \mathrm{p}$ and $\mathrm{R} 95 \mathrm{p} \%$ ) had increased over almost the entire territory of Serbia (Unkašević and Tošić, 2011). In Montenegro, R20 mm decreased in the southwestern areas, whereas positive trends were detected in north-eastern parts of the country (Burić et al., 2015). The annual R95p showed positive trends in central parts of Montenegro (Burić et al., 2015). Frequency of R95p in Croatia showed spatially trends mixed in sign - a weak annual decrease along the coast and in the mountainous regions, while the mainland displayed positive trends (Gajić-Čapka et al., 2015). The SDII trends revealed annual and seasonal increases in Montenegro (Burić et al., 2015). In Croatia, negative trends were present in summer, while in other seasons, they were mixed in sign and mainly insignificant (Gajić-Čapka et al., 2015). The trends in Rx1day and Rx5day were weak in magnitude and mixed in sign (Gajić-Čapka et al., 2015).

Climate variability in Europe is strongly dictated by NAO, especially during winter season. Strong positive phases of the NAO are associated with above-average precipitation over northern Europe and Scandinavia in winter, and below-average precipitation over southern and central Europe (NOAA CPC, 2017). The positive phase of the EA pattern is also associated with above-average precipitation over northern Europe and Scandinavia, whereas below-average precipitation occurrs across southern Europe (NOAA CPC, 2017). The positive phase of the EAWR pattern is generally linked to belowaverage precipitation across central part of Europe (NOAA CPC, 2017).

Table 9 shows that a significant negative correlation was determined between precipitation and the NAO in winter (-0.236--0.498). Similar results were obtained in other regions of Southeast Europe (Burić et al., 2015; Luković et al., 2015). Further, even stronger negative correlation in winter season was found for the EAWR $(-0.388--0.565)$ and particalarly the AO $(-0.544--0.735)$. In addition, significant relation with $\mathrm{AO}$ is determined in 
autumn (-0.282--0.482). In this part of the year, the determined negative correlation is only partially significant. EA pattern significantly conditions precipitation in Bosnia and Herzegovina only in summer season.

Table 9 - Pearson correlation coefficient between seasonal teleconection patterns indices and precipitation in Bosnia and Herzegovina in the 1961 - 2015 periods

\begin{tabular}{|c|c|c|c|c|c|c|c|c|}
\hline \multirow{2}{*}{ Station } & \multicolumn{5}{|c|}{ WINTER } & \multicolumn{4}{c|}{ SPRING } \\
\cline { 2 - 9 } & EA & NAO & EAWR & AO & EA & NAO & EAWR & AO \\
\hline BL & -0.065 & -0.164 & $-0.418^{\mathrm{b}}$ & $-0.556^{\mathrm{a}}$ & -0.113 & -0.099 & -0.150 & -0.191 \\
\hline DB & -0.042 & $-0.236^{\mathrm{d}}$ & $-0.388^{\mathrm{b}}$ & $-0.544^{\mathrm{a}}$ & 0.143 & -0.084 & -0.039 & -0.119 \\
\hline SA & $-0.243^{\mathrm{d}}$ & $-0.329^{\mathrm{c}}$ & $-0.441^{\mathrm{a}}$ & $-0.596^{\mathrm{a}}$ & -0.030 & -0.086 & -0.137 & -0.202 \\
\hline MO & -0.031 & $-0.498^{\mathrm{a}}$ & $-0.565^{\mathrm{a}}$ & $-0.735^{\mathrm{a}}$ & -0.110 & $-0.253^{\mathrm{d}}$ & -0.007 & $-0.361^{\mathrm{b}}$ \\
\hline \multirow{2}{*}{ Station } & \multicolumn{5}{|c}{ SUMMER } \\
\cline { 2 - 10 } & EA & NAO & EAWR & AO & EA & NAO & EAWR & AO \\
\hline BL & $-0.391^{\mathrm{b}}$ & 0.152 & 0.189 & 0.037 & -0.217 & -0.147 & -0.143 & $-0.415^{\mathrm{b}}$ \\
\hline DB & -0.082 & 0.070 & -0.007 & 0.101 & $-0.267^{\mathrm{c}}$ & -0.126 & -0.175 & $-0.282^{\mathrm{c}}$ \\
\hline SA & $-0.285^{\mathrm{c}}$ & 0.167 & 0.072 & 0.074 & -0.213 & -0.163 & $-0.257^{\mathrm{d}}$ & $-0.390^{\mathrm{b}}$ \\
\hline MO & $-0.250^{\mathrm{d}}$ & 0.190 & 0.215 & -0.131 & -0.100 & -0.158 & $-0.257^{\mathrm{d}}$ & $-0.482^{\mathrm{a}}$ \\
\hline
\end{tabular}

Note: Statistical significance at the $99.9 \%\left({ }^{\mathrm{a}}\right), 99 \%\left({ }^{\mathrm{b}}\right), 95 \%\left({ }^{\mathrm{c}}\right)$ and $90 \%\left({ }^{\mathrm{d}}\right)$ level

Table 10 - Pearson correlation coefficient between annual teleconection patterns indices and extreme precipitation indices in Bosnia and Herzegovina in the 1961 - 2015 periods

\begin{tabular}{|c|c|c|c|c|}
\hline Index & NAO & EA & EAWR & AO \\
\hline PRCTOT & $-0.418^{\mathrm{b}}$ & -0.090 & $-0.307^{\mathrm{c}}$ & $-0.621^{\mathrm{a}}$ \\
\hline RX1day & $-0.244^{\mathrm{d}}$ & -0.040 & -0.139 & $-0.251^{\mathrm{d}}$ \\
\hline RX5day & $-0.037^{\mathrm{d}}$ & 0.037 & -0.042 & -0.137 \\
\hline SDII & $-0.257^{\mathrm{d}}$ & 0.154 & $-0.247^{\mathrm{d}}$ & $-0.389^{\mathrm{b}}$ \\
\hline R1mm & $-0.376^{\mathrm{b}}$ & -0.103 & $-0.236^{\mathrm{d}}$ & $-0.434^{\mathrm{a}}$ \\
\hline R10mm & $-0.447^{\mathrm{a}}$ & -0.050 & $-0.314^{\mathrm{c}}$ & $-0.634^{\mathrm{a}}$ \\
\hline R20mm & $-0.385^{\mathrm{b}}$ & -0.043 & $-0.358^{\mathrm{b}}$ & $-0.519 \mathrm{a}$ \\
\hline R95p & $-0.253^{\mathrm{d}}$ & 0.075 & -0.198 & $-0.359^{\mathrm{b}}$ \\
\hline R99p & -0.210 & 0.087 & $-0.312^{\mathrm{c}}$ & $-0.264^{\mathrm{d}}$ \\
\hline CWD & -0.150 & -0.034 & -0.157 & -0.116 \\
\hline CDD & 0.182 & 0.057 & 0.125 & 0.161 \\
\hline
\end{tabular}

Note: Statistical significance at the $99.9 \%\left({ }^{a}\right), 99 \%\left({ }^{b}\right), 95 \%\left(^{c}\right)$ and $90 \%\left({ }^{d}\right)$ level 
The investigated precipitation indices seemed to be directly linked to changes in the dominant large-scale circulation patterns over Northern Hemisphere. Table 10 shows that statistically significant negative correlation with NAO, EAWR and AO is found for majority of extreme precipitation indices in Bosnia and Herzegovina - PRCTOT, SDII, R1mm, R10mm, R20mm, R99p (except for NAO) and RX1 day and R95p (except for EAWR).

\section{Conclusion}

The study analyzes trends in extreme daily precipitation indices in Bosnia and Herzegovina. Trends in 13 indices recommended by the ETCCDI were calculated for the 1961-2015 periods using RClimDex (1.0) software. The obtained results suggest that a general increase in the extreme precipitation is present over the territory of Bosnia and Herzegovina. Upward trends in heavy precipitation events such as RX1 day, RX5 day, SDII, $\mathrm{R} 10 \mathrm{~mm}, \mathrm{R} 20 \mathrm{~mm}, \mathrm{R} 95 \mathrm{p} \mathrm{R} 95 \mathrm{p} \%, \mathrm{R} 99 \mathrm{p}$ and R99p\% indicate changes toward more intense precipitation over the study area. However, most of the estimated trend values are statistically insignificant. Also, trends are not spatially and temporally coherent. Spatially incoherent patterns of change with the occurrence of trends of both sign were registered. Indices that have been calculated seasonally show that there are also variations between change patterns throughout year. Trends that indicate increase in either the frequency or intensity of heavy precipitation are generally most prominent in Doboj area. Exceptionally high rainfall amount that caused catastrophic flooding has been recorded several times just during the last decade. In May and August 2014, for just a few days $146.6 \mathrm{~mm}$ and $123.6 \mathrm{~mm}$ of precipitation was registered, which is $17 \%$ and $14 \%$ of average annual precipitation in a standard climatological period (1961-1990). Similar weather conditions have occurred in June 2010 when for only two days $178.3 \mathrm{~mm}$ of rainfall was recorded (20\% of annual totals). The observed extreme precipitation trends are directly related with changes in the large-scale circulation patterns over Northern Hemisphere. Statistically significant negative correlation with $\mathrm{NAO}, \mathrm{EAWR}$ and $\mathrm{AO}$ is found for majority of extreme precipitation indices, particularly during winter. The results obtained in this survey are similar to the results of other studies that addressed the issue of recent extreme daily precipitation indices in the adjacent regions of Southeast Europe. Due to the heavy precipitation event large impact on natural and socio-economic systems, further research is certainly necessary. 


\section{Acknowledgements}

The paper is the result of the research within the project "Modeling extreme precipitation under climate scenarios in the Republic of Srpska" (No. 19/6-020/961$57 / 15)$ funded by the Ministry of Science and Technology of the Republic of Srpska.

\section{References}

Alexander, L.V., \& Arblaster, J.M. (2017). Historical and Projected Trends in Temperature and Precipitation Extremes in Australia in Observations and CMIP5. Weather and Climate Extremes, 15, 34-56. doi: 10.1016/j.wace.2017.02.001

Balling Jr., R.C., Kiany, M.S.K., Sen Roy, S., \& Khoshhal, J. (2016). Trends in Extreme Precipitation Indices in Iran: 1951-2007. Advances in Meteorology, 2016, doi: 10.1155/2016/2456809

Bartolomeu, S., Carvalho, M.J., Marta-Almeida, M., Melo-Gonçalves, P., \& Rocha, A. (2016). Recent Trends of Extreme Precipitation Indices in the Iberian Peninsula Using Observations and WRF Model Results. Physics and Chemistry of the Earth, Parts A/B/C, 94, 10-21. doi: 10.1016/j.pce.2016.06.005

Burić, D.,Luković, J., Bajat, B., Kilibarda, M., \&Živković, N. (2015). Recent Trends in Daily Rainfall Extremes over Montenegro (1951-2010). Natural Hazards and Earth System Sciences, 15, 2069-2077. doi: 10.5194/nhess-15-2069-2015

de Lima, M.I.P., Santo, F.E., Ramos, A.M., \& Trigo, R.M. (2015). Trends and Correlations in Annual Extreme Precipitation Indices for Mainland Portugal, 1941-2007. Theoretical and Applied Climatology, 119(1), 55-75. doi: 10.1007/s00704-013-1079-6

de Luis, M., Čufar, K., Saz, M.A., Longares, L.A., Ceglar, A., \& KajfežBogataj, L. (2014). Trends in Seasonal Precipitation and Temperature in Slovenia during 1951-2007. Regional Environmental Change, 14(5), 1801-1810. doi: 10.1007/s10113-012-0365-7

de Melo, T.M., Louzada, J.A.S., \& Pedrollo, O.C. (2015). Trends in Extreme Indices and Seasonal Analysis of Precipitation and Temperature in the Northwest Region of Rio Grande do Sul, Brazil. American Journal of Climate Change, 4, 187-202. doi: 10.4236/ajcc.2015.43015

Donat, M.G., Alexander, L.V., Yang, H., Durre, I., Vose, R., Dunn, R.J.H., Willett, K.M., Aguilar, E., Brunet, M., Caesar, J., Hewitson, B., Jack, C., Klein Tank, A.M.G., Kruger, A.C., Marengo, J., Peterson, T.C., Renom, M., Oria 
Rojas, C., Rusticucci, M., Salinger, J., Elrayah, A.S., Sekele, S.S., Srivastava, A.K., Trewin, B., Villarroel, C., Vincent, L.A., Zhai, P., Zhang, X., \& Kitching, S. (2013). Updated Analyses of Temperature and Precipitation Extreme Indices since the Beginning of the Twentieth Century: The Hadex2 Dataset. Journal of Geophysical Research: Atmospheres, 118, 1-16, doi: 10.1002/jgrd.50150

Ducić, V., Burić, D., Trbić, G., \& Cupać, R. (2014). Analysis of Precipitation and Droughts on BIH Territory Based Upon Standardized Precipitation Index (SPI). HERALD, 18, 53-70. doi: 10.7251/ HER1814053D

ETCCDI (2009). Climate Change Indices, Definitions of the 27 Core Indices. Retrieved from http://etccdi.pacificclimate.org/list_27_indices.shtml

Fan, L., \& Chen, D. (2016). Trends in Extreme Precipitation Indices Across China Detected Using Quantile Regression. Atmospheric Science Letters, 17(7), 400-406. doi: 10.1002/asl.671

Filahi, S., Tanarhte, M., Mouhir, L., El Morhit, M., \& Tramblay, Y. (2016). Trends in Indices of Daily Temperature and Precipitations Extremes in Morocco. Theoretical and Applied Climatology, 124(3), 959-972. doi: 10.1007/ s00704-015-1472-4

Gajić-Čapka, M., Cindrić, K., \& Pasarić, Z. (2015). Trends in Precipitation Indices in Croatia, 1961-2010. Theoretical and Applied Climatology, 121(1), 167-177. doi: 10.1007/s00704-014-1217-9

Hartmann, D.L., Klein Tank, A.M.G., Rusticucci, M., Alexander, L.V., Brönnimann, S., Charabi, Y., Dentener, F.J., Dlugokencky, E.J., Easterling, D.R., Kaplan, A., Soden, B.J., Thorne, P.W., Wild, M., \& Zhai, P.M. (2013). Observations: Atmosphere and Surface. In: T.F. Stocker, D. Qin, G.K. Plattner, M. Tignor, S.K. Allen, J. Boschung, A. Nauels, Y. Xia, V. Bex \& P.M. Midgley (Eds.) Climate Change 2013: The Physical Science Basis, Contribution of Working Group I to the Fifth Assessment Report of the Intergovernmental Panel on Climate Change (pp. 159-254). Cambridge: Cambridge University Press.

IPCC (2014). Climate Change 2014: Synthesis Report. Contribution of Working Groups I, II and III to the Fifth Assessment Report of the Intergovernmental Panel on Climate Change [Core Writing Team, Pachauri, R.K., \& Meyer, L.A. (Eds.)]. Geneva: IPCC

Lojović, M. \& Gnjato, O. (2016). Sustainable Development of Tourism in East Herzegovina. Collection of Papers - Faculty of Geography at the University of Belgrade, 64, 381-399, doi:10.5937/zrgfub1664361L 
Luković, J., Bajat, B., Blagojević, D., \& Kilibarda, M. (2014). Spatial Pattern of Rainfall Trend in Serbia, Regional Environmental Change, 14(5), 1789-1799. doi: 10.1007/s10113-013-0459-x

Luković, J., Blagojevć, D., Kilibarda, M., \& Bajat, B. (2015). Spatial Pattern of North Atlantic Oscillation Impact on Rainfall in Serbia. Spatial Statistics, 14(Part A), 39-52. doi: 10.1016/j.spasta.2015.04.007

Mihailović, D.T., Drešković, N., \& Mimić, G. (2015). Complexity Analysis of Spatial Distribution of Precipitation: An Application to Bosnia and Herzegovina. Atmospheric Science Letters, 16(3), 324-330. doi: 10.1002/asl2.563

Miladinović, S.Đ. \& Gavrilović, Lj.M. (2012). Estimates of Endangerment and Protection from Torrential Floods on Smederevo Territory, Collection of Papers - Faculty of Geography at the University of Belgrade, 60, 155-174.

Milinčić, M., Tucović, M. \& Mandić, B. (2013). Some Aspects of Agricultural Influence on the Environment. Collection of Papers - Faculty of Geography at the University of Belgrade, 61, 31-58.

NOAA National Weather Service Climate Prediction Center (NOAA CPC) (2017). Northern Hemisphere Teleconnection Patterns. Retrieved from http://www.cpc.ncep.noaa.gov/data/teledoc/telecontents.shtml

Rvović, M. (2014). Integral Basis for the Development of Ecotourism in the Municipality of Prijepolje. Collection of Papers - Faculty of Geography at the University of Belgrade, 62, 197-222.

Santos, C.A.C., \& de Oliveira, V.G. (2017). Trends in Extreme Climate Indices for Pará State, Brazil. Revista Brasileira de Meteorologia, 32(1), 13-24. doi: 10.1590/0102-778632120150053

Sheikh, M.M., Manzoor, N., Ashraf, J., Adnan, M., Collins, D., Hameed, S., Manton, M. J., Ahmed, A.U., Baidya, S.K., Borgaonkar, H.P., Islam, N., Jayasinghearachchi, D., Kothawale, D.R., Premalal, K.H.M.S., Revadekar, J.V., \& Shrestha, M.L. (2015). Trends in Extreme Daily Rainfall and Temperature Indices over South Asia. International Journal of Climatology, 35(7), 1625-1637. doi: 10.1002/joc.4081

Trbić, G., Popov, T., \& Gnjato, S. (2017). Analysis of Air Temperature Trends in Bosnia and Herzegovina. Geographica Pannonica

Unkašević, M., \& Tošić, I. (2011). A Statistical Analysis of the Daily Precipitation over Serbia: Trends and Indices. Theoretical and Applied Climatology, 106(1), 69-78. doi: 10.1007/s00704-011-0418-8 
Zhang, X., \& Yang, F. (2004). RClimDex (1.0) User Manual. Downsview, Ontario, Canada: Climate Research Branch Environment Canada.

Živanović, V. (2014). Natural Potentials in the Function of Regional Development and Differentiation of the Podrinje Region. Collection of Papers - Faculty of Geography at the University of Belgrade, 62, 61-90. 